\title{
LIBERDADE DE EXPRESSÃO E DIREITO À INFORMAÇÃO: OS LIMITES DA ATIVIDADE JORNALÍSTICA SOB A ÓTICA DO STF E DO STJ
}

\author{
Andressa de Bittencourt Vieira Dantas* \\ Camila Figueiredo Oliveira Gonçalves**
}

1 Introdução. 2 Limites éticos e legais da atividade jornalística. 2.1 Responsabilidade civil. 2.2 Responsabilidade penal. 2.3 Direito de resposta. $3 \mathrm{~A}$ atividade jornalística sob a ótica dos tribunais superiores. 3.1 Colisão de direitos fundamentais. 3.2 Análise jurisprudencial. 3.2.1 Jornalismo em pauta: o mérito da questão. 4 Conclusões. Referências.

\section{RESUMO}

Liberdade de expressão e direito à informação são os direitos fundamentais que balizam a atividade jornalística. Por seu caráter relativo, no entanto, podem entrar em rota de colisão com outros direitos, como a honra, a imagem e a privacidade. Este trabalho tem como objetivos, portanto, explicitar os limites éticos legais e as responsabilidades jurídicas atribuíveis a jornalistas e veículos de comunicação em razão do exercício profissional; estudar a regra da proporcionalidade como método de resolução de conflitos entre direitos fundamentais; analisar o entendimento jurisprudencial dos tribunais superiores acerca do conflito entre liberdade de expressão e direito à informação versus outros direitos fundamentais e como tais princípios têm sido relativizados. Dessa forma, são analisadas 41 decisões proferidas pelo Supremo Tribunal Federal e pelo Superior Tribunal de Justiça no período entre 30/04/2009 e 30/04/2015, com o intuito de esclarecer quais dos direitos em conflito têm ou não prevalecido nos casos concretos, buscando chegar a uma

* Graduada em Jornalismo pela Universidade Federal do Ceará - UFC; Graduada em Direito pelo Centro Universitário Christus - UNICHRISTUS. Advogada. E-mail: <andressabitten@gmail.com>.

** Mestre em Direito Constitucional nas Relações Privadas pela Universidade de Fortaleza (Bolsista Funcap e PROSUP/Capes) (2014). Especialista em Direito Público (2013). Bacharel em Direito pela Universidade Federal do Ceará com distinção acadêmica Magna Com Laude (2012). Atualmente é Coordenadora de Atividades Complementares e Professora de Direito Civil do Centro Universitário Christus - Unichristus. Tem experiência na área de Direito Civil, atuando, principalmente, nos seguintes temas: Teoria Geral do Direito Privado, Biodireito, Direitos da Personalidade, Responsabilidade Civil, Direito de Família, Direito das Sucessões, Direito Contratual e Direito das Coisas. E-mail: <camilafogoncalves@gmail.com>. 
resposta o mais fidedigna possível quanto aos reais limites da atuação jornalística e compreender se o que tem sido julgado tem criado precedentes. A pesquisa é feita de forma quali-quantitativa, descritiva e indutiva. $\bigcirc$ trabalho justifica-se pelo ineditismo da abordagem da temática e pela carência de estudos acadêmicos que tratem do embate entre liberdade de expressão e direito à informação versus outros direitos fundamentais pelo viés empírico. Os resultados buscam auxiliar a reflexão acerca do exercício midiático, avaliando de que forma a atividade jornalística pode servir à sociedade sem cometer atos ilícitos ou abusar de seus direitos balizadores.

Palavras-chave: Liberdade de Expressão. Direito à Informação. Colisão de Direitos Fundamentais. Jurisprudência. Tribunais Superiores.

\section{INTRODUÇÃO}

A atividade jornalística é balizada por dois importantes direitos fundamentais: a liberdade de expressão e o direito à informação. Tais direitos estão previstos na Declaração Universal dos Direitos Humanos de 1948, que, em seu artigo XIX, garante a todo homem a liberdade de opinião e expressão, incluindo a liberdade de "sem interferência, ter opiniões e de procurar, receber e transmitir informações e ideias por quaisquer meios e independentemente de fronteiras" .

Os citados direitos fundamentais também são garantidos pela Constituição Federal de 1988. Como direito inerente à pessoa humana, a liberdade de expressão faz parte do conjunto dos direitos e deveres individuais e coletivos, expresso nos artigos $5^{\circ}$, IV, VIII, IX, e $220, \S 2^{\circ}$, que garantem a livre manifestação do pensamento, da criação, da expressão e da informação; a liberdade de crença religiosa, convicção filosófica ou política; e a livre expressão da atividade intelectual, artística, científica e de comunicação, independentemente de licença ou censura de natureza política, ideológica e artística.

O direito à informação, por sua vez, faz parte da quarta dimensão dos direitos fundamentais, na definição de Bonavides, ${ }^{2}$ ao lado da democracia e do pluralismo, isto é, ultrapassa o âmbito individual e passa a ter caráter coletivo. Está previsto no art. $5^{\circ}$ da Constituição vigente, nos incisos XIV, XXXIII e XXXIV, b, e 220, $\S 1^{\circ}$, que asseguram o acesso à informação e o resguardo ao sigilo da fonte; o direito de receber dos órgãos públicos informações de seu interesse particular, ou de interesse coletivo ou geral; a obtenção de certidões em repartições públicas, para defesa de direitos e esclarecimento de situações de interesse pessoal; e a vedação do embaraço à plena liberdade de informação jornalística em qualquer veículo de comunicação social.

No plano infraconstitucional, a Lei 12.527/11 dispõe sobre o acesso à informação, e a Convenção Americana sobre Direitos Humanos (Pacto de San José da 
Costa Rica) - promulgada pelo Decreto ${ }^{\circ}$ 678/92 - determina, em seu artigo 13, ser direito de toda pessoa a "liberdade de procurar, receber e difundir informações e ideias de qualquer natureza, sem considerações de fronteiras, verbalmente ou por escrito, ou em forma impressa ou artística, ou por qualquer meio de sua escolha"3.

Liberdade de expressão e direito à informação, portanto, direcionam a atividade jornalística para seus objetivos: informar, orientar e proporcionar uma sociedade mais democrática. Contudo, em razão do caráter relativo dos direitos fundamentais, podem entrar em rota de colisão com outros direitos, como a honra, a imagem e a vida privada. Diante do conflito entre prerrogativas constitucionais de importância equivalente, o juiz deve lançar mão da regra da proporcionalidade, a fim de limitar o exercício de um ou de ambos os direitos.

Ademais, é importante notar que, ao passo que tem sua atividade balizada por direitos constitucionalmente previstos, o jornalismo também cumpre um dever - ou, como diriam os pesquisadores da comunicação, exerce uma função em prol da sociedade.

A imprensa livre, como instituição protegida, na sua função informativa, possui um direito-dever, tradicionalmente atribuído aos jornalistas. Assim, tem a prerrogativa de investigar, tratar e transmitir material de interesse público, mas também de informar

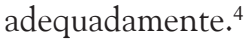

Dessa forma, os profissionais da mídia, quando realizam uma investigação jornalística, não podem abusar do direito de informar, mas se utilizar dele - enquanto dever, no sentido deontológico do termo - com vistas à concretização da função social que o jornalismo se propõe a ter.

Cumpre, então, questionar: se a liberdade de expressão e o direito à informação não são direitos absolutos, de que forma o exercício desses direitos é restringido diante da colisão com outros direitos fundamentais? Como se manifestam os limites do exercício midiático para os jornalistas e os veículos de comunicação? E, por fim, qual tem sido a posição dos tribunais superiores nos julgados que envolvem liberdade de expressão e direito à informação versus outros direitos fundamentais?

Com o fito de buscar respostas a esses questionamentos, esta pesquisa tem como objetivos: explicitar os limites éticos legais e as responsabilidades jurídicas atribuíveis aos jornalistas e aos veículos de comunicação em razão do exercício profissional; estudar a regra da proporcionalidade - e suas três sub-regras como método de resolução de conflitos entre direitos fundamentais; analisar o entendimento jurisprudencial dos tribunais superiores acerca do conflito entre liberdade de expressão e direito à informação versus outros direitos fundamentais e como tais princípios têm sido relativizados.

O trabalho é feito de forma quali-quantitativa, descritiva e indutiva. São analisadas 41 decisões proferidas pelo Supremo Tribunal Federal e pelo Superior Tribunal de Justiça no período entre 30 de abril de 2009 (data da não recepção 
da Lei de Imprensa - Lei n 5.250/67 - pela ADPF 130) e 30 de abril de 2015, com o intuito de esclarecer quais dos direitos em conflito têm ou não prevalecido nos casos concretos, buscando chegar a uma resposta o mais fidedigna possível quanto aos reais limites da atuação jornalística e compreender se o que tem sido julgado desde 2009 tem criado precedentes, ou seja, fortalecido a previsibilidade das decisões.

A pesquisa justifica-se pelo ineditismo da abordagem da temática e pela carência de estudos acadêmicos que tratem do embate entre liberdade de expressão e direito à informação versus outros direitos fundamentais pelo viés empírico. Os resultados encontrados, embora não generalizáveis, auxiliam na reflexão acerca do exercício midiático: até que ponto os profissionais da mídia podem ultrapassar as barreiras legais em nome do interesse público? Os fins justificam os meios? De que forma a atividade jornalística pode servir à sociedade sem cometer atos ilícitos ou abusar da liberdade de expressão e do direito à informação?

\section{LIMITES ÉTICOS E LEGAIS DA ATIVIDADE JORNALÍSTICA}

Liberdade de expressão e direito à informação são os direitos fundamentais que balizam a atividade jornalística. Embora a efetivação desses direitos esteja garantida pela Constituição Federal de 1988, pela Lei 12.527/11 e pelo Decreto $n^{\circ} 678 / 92$, o modo de atuação e os meios permitidos ou proibidos ao exercício midiático estão mais bem disciplinados no Código de Ética dos Jornalistas Brasileiros, de 2007, que é o único parâmetro profissional vigente desde a não recepção da Lei de Imprensa (Lei 5.250/67) pela ADPF 130, em abril de 2009. Entretanto, o Código não tem força de lei, apenas servindo para levar à frente a reflexão acerca das formas de realização e abordagem de reportagens, uma vez que os métodos utilizados pelos profissionais podem gerar excessos passíveis de sanções legais.

Assim ocorre, por exemplo, quando os jornalistas lançam mão de identidades falsas, câmeras escondidas ou microfones ocultos para obter informações, o que é expressamente vedado pelo Código de Ética (art. 11, III), "salvo em casos de incontestável interesse público e quando esgotadas todas as outras possibilidades de apuração".

Esses instrumentos não são dificilmente encontrados em procedimentos de investigação jornalística. No entanto, cabe às normas jurídicas gerais - e não ao Código de Ética - tratar das punições no caso de alguma das condutas praticadas por jornalistas configurar ilícito civil ou penal por violar direitos, como a honra, a imagem, a intimidade, entre outros.

\subsection{Responsabilidade civil}

Não é incomum jornalistas e veículos de comunicação serem acionados judicialmente para responder pelo exercício da profissão. Quando há excesso 
midiático, ou seja, quando a imprensa atua além dos limites éticos e/ou legais, ferindo direitos de outrem, a vítima pode buscar a reparação pelos danos que lhe foram causados, conforme determina a Constituição Federal de 1988 (art. 5, V e X), o Código Civil de 2002 (arts. 20, 186 e 927) e o Código de Ética dos Jornalistas Brasileiros (art. $6^{\circ}$, inciso VIII) ${ }^{6}$

Situações assim ocorrem porque, além da liberdade de expressão e do direito à informação, também são considerados direitos fundamentais a vida privada, a honra, a intimidade e a imagem do cidadão, que podem ser alguns dos direitos violados pelo exercício irregular do jornalismo.

No âmbito civil, via de regra, a responsabilidade da imprensa é a subjetiva, ${ }^{7}$ exigindo a existência de dolo ou culpa quando do cometimento do ilícito, podendo ser imputada tanto ao jornalista quanto ao veículo de comunicação, conforme disposto na Súmula 221 do STJ. Ela segue, portanto, os requisitos exigidos pelo artigo 186 do Código Civil: haver ação ou omissão voluntária, dolo ou culpa, violação de direito, danos (ainda que exclusivamente moral) e nexo causal entre a conduta e o resultado.

Em suma, o excesso midiático pode atingir uma gama de direitos fundamentais e da personalidade, fazendo que o ofendido possa buscar a reparação pelos danos causados pela imprensa. A responsabilidade civil dos jornalistas e dos meios de comunicação se dá, prioritariamente, por meio das ações de reparação de danos, tanto morais quanto materiais. ${ }^{8}$

A indenização por danos morais é cabível quando a violação a direito ofende a integridade e a moral do ser humano, ${ }^{9}$ embora também possa resultar em prejuízo ao patrimônio. É violação que atinge a dignidade humana, cujo conceito jurídico, segundo Moraes, seria composto por quatro fundamentos: o direito à igualdade (formal e substancial); a tutela da integridade psicofísica (completo bem estar psicofísico e social); o direito à liberdade (consubstanciada, enquanto liberdade individual, no poder de realizar as próprias escolhas individuais sem interferências, numa perspectiva de privacidade, de intimidade, de vida privada); o direito-dever de solidariedade (conjunto de instrumentos voltados para garantir uma existência digna, comum a todos, sem excluídos ou marginalizados, em uma sociedade que se desenvolva como livre e justa). ${ }^{10} \mathrm{Na}$ concepção da autora, "todas as situações graves o bastante para gerar a reparação por dano moral devem poder ser reconduzidas a pelo menos um desses quatro princípios". ${ }^{11} \mathrm{~A}$ indenização por danos materiais, por sua vez, é cabível quando há a ofensa ao patrimônio material ou imaterial da vítima. Desdobra-se em danos emergentes e lucros cessantes, assim definidos por Dias:

Os efeitos do ato danoso incidem no patrimônio atual, cuja diminuição ele acarreta. Pode suceder, contudo, que esses efeitos se produzam em relação ao futuro, impedindo ou diminuindo o benefício patrimonial a ser deferido à vítima. Aí estão identificados o dano positivo ou damnum emergens e o lucro frustrado ou lucrum cessans. ${ }^{12}$ 
Os danos materiais estão previstos no Código Civil, em seu artigo 402, determinando que "salvo as exceções expressamente previstas em lei, as perdas e danos devidas ao credor abrangem, além do que ele efetivamente perdeu, o que razoavelmente deixou de lucrar".

A indenização, cumpre frisar, é uma forma de ressarcimento ou reparação do dano, mas, segundo alguns autores, como Dias, dificilmente alcança o status quo ante, sobretudo quando se trata do dano moral. A transformação em valor não significa a restituição da coisa ou da dignidade, quando se trata de ofensa aos direitos fundamentais aqui tratados.

\subsection{Responsabilidade penal}

A violação ao interesse privado pelo excesso midiático, além da reparação civil, enseja, a depender do caso, a responsabilidade penal, que se manifesta por meio das sanções criminais, muito embora haja autores que defendam que a sanção pelo excesso no exercício da liberdade de expressão se restrinja à esfera cível. ${ }^{13}$ Carvalho sintetiza: "conforme a natureza do interesse violado, varia o modo de reação do ordenamento jurídico". ${ }^{14}$

A responsabilidade penal da imprensa era tutelada pela Lei 5.250/67, que trazia, além de capítulo tipificando as condutas que consistiam em abusos no exercício da liberdade de manifestação do pensamento e da informação, um capítulo específico elencando os responsáveis para arcar com os efeitos penais desses excessos.

Antes, a responsabilidade no âmbito penal era sucessiva, respondendo, em primeiro lugar, o autor do escrito ou da transmissão incriminada, ou, na ausência deste, o diretor ou redator-chefe do jornal ou da emissora de televisão, conforme determinava o artigo 37. Hoje, devido à responsabilização da pessoa jurídica ser exceção, ${ }^{15}$ manifestando-se apenas quanto aos crimes ambientais, ${ }^{16}$ somente os jornalistas e, de qualquer forma, colaboradores de veículos de comunicação (ex. colunistas, chargistas, editores) podem ser sancionados se houver a prática de crimes tipicamente previstos no Código Penal.

A responsabilidade penal dos profissionais da imprensa pode-se dar mediante dois tipos de conduta: uma tem a ver com o conteúdo do que é noticiado; a outra se relaciona com os métodos de obtenção das informações.

A primeira hipótese ocorre, sobretudo, quando os jornalistas cometem os crimes contra a honra, previstos no Código Penal sob a forma de calúnia, difamação e injúria (artigos 138 a 145). Já o segundo caso, em que o jornalista pode ser responsabilizado penalmente ocorre quando os métodos de obtenção das informações ferem a legalidade. Acontece, por exemplo, com a utilização da falsa identidade, prevista nos artigos 307 e 308 do Código Penal.

A norma é clara ao determinar que, para haver crime nesse último caso, é necessário que o agente tenha atribuído falsa identidade para si ou para terceiro 
com o fito de obter vantagem em proveito próprio ou alheio ou para causar dano. É também considerado crime de falsa identidade quando o agente utiliza, como próprio, passaporte, título de eleitor, caderneta de reservista ou qualquer documento de identificação alheia ou cede a outrem, para que dele se utilize, documento dessa natureza, próprio ou de terceiro.

Outra hipótese que suscita discussões é a utilização de câmeras escondidas e grampos telefônicos. Diferentemente do que se possa imaginar, a escuta telefônica ou ambiental e a gravação clandestina não constituem, em regra, crimes. Tratam-se, nesse caso, de hipóteses permitidas pela lei, tendo em vista que "qualquer pessoa tem o direito de gravar a sua própria conversa, haja ou não conhecimento da parte de seu interlocutor. O que a lei penal veda, tornando ilícita a prova decorrente, é a divulgação da conversa sigilosa, sem justa causa". ${ }^{17}$ No entanto, a utilização de qualquer desses métodos, quando fere a privacidade, constituem ilícitos passíveis de sanções. Trata-se, por exemplo, da interceptação telefônica (também conhecida como interceptação stricto sensu ou "grampo") e da ambiental. ${ }^{18}$

É necessário esclarecer que a imputação de qualquer desses crimes a um jornalista deve levar em consideração o processo penal que, em primeiro lugar, analisa a conduta do agente a partir de sua intenção. Tanto a injúria, a difamação, a calúnia, a interceptação telefônica e o crime de falsa identidade são delitos dolosos.

Assim, é no processo judicial, em que se irá aferir se a conduta do jornalista, quando da prática de ilícitos no exercício da profissão, foi conduzida por uma vontade deliberada de causar dano a bem jurídico ou violar a norma positivada.

\subsection{Direito de resposta}

O direito de resposta é um direito potestativo, extrajudicial, contido no rol de direitos fundamentais e previsto no artigo $5^{\circ}$, inciso V, da Constituição vigente, que dispõe ser "assegurado o direito de resposta, proporcional ao agravo, além da indenização por dano material, moral ou à imagem”.

Durante quase sete anos, isto é, desde a não recepção da Lei de Imprensa, em abril de 2009, até novembro de 2015 - quando foi sancionada a Lei 13.188/15, que dispõe sobre o direito de resposta ou retificação do ofendido em matéria divulgada, publicada ou transmitida por veículo de comunicação social -, esse direito foi regido unicamente pela Constituição de 1988, que não prevê detalhamento algum de como pode ser posto em prática, tendo restado à doutrina refletir sobre as possibilidades de concretização e gerando críticas por parte de pesquisadores como Bôaviagem:

O direito de resposta contava com tratamento bem delineado pela revogada Lei de Imprensa, quanto à titularidade, seu conteúdo, seus prazos, sua forma, e as sanções pelo seu não atendimento. A ausência da lei de regência traz um risco, pelo vácuo, e para o 
qual alertou o Ministro Gilmar Mendes, qual seja o de habilitar o direito de resposta a construções as mais variadas, exóticas mesmo. ${ }^{19}$

A nova lei tem a pretensão de suprir tal vácuo normativo, estipulando novos prazos e condições para o exercício do direito de resposta: aquele que tiver a honra, a intimidade ou a reputação violada pode solicitar diretamente ao veículo de comunicação social, em até 60 dias a contar da publicação da matéria ofensiva ou inverídica, um pedido de retratação. O veículo tem até sete dias para conceder o espaço ao ofendido; caso contrário, o direito de resposta pode ser pleiteado em juízo. Se a decisão judicial for favorável à vítima, em até 10 dias deve ser veiculada a retificação ou resposta do ofendido, conforme as condições fixadas pelo juiz. ${ }^{20}$

Dessa forma, o exercício do direito de resposta tem como pressuposto o agravo sofrido pelo ofendido - como determina o artigo $5^{\circ}$, inciso $\mathrm{V}$, da $\mathrm{CF} / 88$ -, que pode ser interpretado como: (a) informação inverídica; (b) informação ofensiva, independentemente de sua veracidade; (c) apreciação injusta sobre uma pessoa ou coletividade. Oliveira, Falleiros e Mendes destacam que as três hipóteses devem ser consideradas necessariamente sob um ponto de vista objetivo e não do ponto de vista exclusivo do ofendido:

Esses três pressupostos fáticos (ou desdobramentos) englobam simultaneamente o direito individual de ser representado pela mídia da forma como alguém vê a si próprio e o direito metaindividual, cujo titular é toda a sociedade, à informação verdadeira. Além disso, esses pressupostos fáticos não prejudicam o exercício da liberdade de imprensa, uma vez que eles impedem o exercício do direito de resposta sempre que uma informação verdadeira é divulgada no interesse da sociedade ou quando uma crítica sobre uma pessoa ou coletividade não venha a causar desconforto algum, sob um ponto de vista objetivo. ${ }^{21}$

Chehab resume, portanto, o conceito de direito de resposta: "[...] é aquele que possui o ofendido de apresentar sua defesa, versão e argumentos no mesmo veículo de imprensa que o ofendeu, com o mesmo espaço ou horário e com idêntico destaque e sem qualquer custo por isso". ${ }^{22} \mathrm{O}$ ofendido tanto pode ser pessoa física, jurídica, órgão ou entidade pública.

Schreiber defende as formas não pecuniárias de reparação de danos em detrimento das indenizações, sob o argumento de que aquelas seriam mais eficazes quanto à reparação integral da vítima, enquanto estas, em razão de, muitas vezes, serem fixadas em patamares genéricos, seriam incapazes de desestimular abusos em massa:

A insuficiência da quantia é, não raro, sentida pela vítima como nova afronta à sua dignidade, corroborada pela postura "comercial" muitas vezes adotada, mesmo em salas de audiência, por ofensores habituais e seus prepostos. Daí a conveniência de aduzir ao pagamento medidas de retratação e de publicidade da reparação, que efetivamente compensam o desvalor moral sofrido pela vítima. ${ }^{23}$ 
Diante desse quadro, não é difícil imaginar que o direito de resposta tenha sido menos utilizado em face das indenizações pecuniárias durante o período de vácuo normativo. No entanto, apenas analisando a jurisprudência pátria, será possível concluir como foram julgados os litígios envolvendo o exercício da imprensa entre 2009 e 2015 e, caso haja condenações em razão de violação a direitos fundamentais e da personalidade - como a honra, a imagem, a intimidade e a vida privada -, que condenações são essas: reparação de danos por meio de indenização pecuniária, retratação do jornalista e do veículo ou publicação da resposta dos ofendidos nos meios de comunicação?

\section{A ATIVIDADE JORNALÍSTICA SOB A ÓTICA DOS TRIBUNAIS SUPERIORES}

O jornalismo, quando se vale da liberdade de expressão e do direito à informação, pode ou não contribuir para o exercício da cidadania e da democracia. Porém, se a intimidade, a privacidade, a honra ou outros direitos constitucionalmente garantidos forem violados em nome de uma função social do jornalismo, é dever do juiz decidir qual desses direitos deve ter seu exercício restringido ou não.

Além disso, quando da busca pela concretização de um dever profissional, os jornalistas podem ultrapassar limites legais e, da mesma forma, violar direitos fundamentais, suscitando questões jurídicas e éticas que balizam a profissão.

Dessa forma, é necessário entender como a atividade midiática tem sido vista pelos tribunais superiores, isto é, diante do conflito entre a liberdade de expressão e o direito à informação em face de outros direitos fundamentais e da personalidade, em que medida o Supremo Tribunal Federal e o Superior Tribunal de Justiça têm restringido o exercício de cada um desses direitos?

\subsection{Colisão de direitos fundamentais}

A Constituição Federal vigente alberga um rol de direitos fundamentais. Além do art. $5^{\circ}$, que prevê os direitos à igualdade, à liberdade, à propriedade, à intimidade, à vida privada e à livre manifestação do pensamento, por exemplo, outros dispositivos esparsos trazem direitos a mais, como a igualdade tributária (art. 150, II), o meio ambiente ecologicamente equilibrado (art. 225) e a comunicação social (art. 220).

Tendo em vista que o conteúdo essencial desses direitos pode ser parcial ou totalmente colidente entre si, é dever do juiz disciplinar a convivência deles em cada caso concreto, determinando a medida de aplicação de cada um. Silva exemplifica: segundo as condições fáticas e jurídicas presentes, a liberdade de expressão é um princípio que deve ser realizado na maior medida possível, "ou seja, a liberdade de poder se exprimir deve ser otimizada. Diante disso, é fácil perceber que essa otimização pode colidir com a otimização do direito à privacidade, que também é um princípio". ${ }^{24}$ 
Isso ocorre porque, segundo Alexy, ${ }^{25}$ a maioria das normas de direitos fundamentais tem estrutura de princípios ${ }^{26} \mathrm{e}$ é aplicada de forma gradativa, isto é, a partir do momento em que essas normas são consideradas mandamentos de otimização, são realizadas "na maior medida possível diante das possibilidades fáticas e jurídicas existentes" ${ }^{27}$. Em se tratando de princípios, não se pode falar em realização sempre total daquilo que a norma exige; "Ao contrário: em geral, essa realização é apenas parcial. Isso, porque, no caso dos princípios, há uma diferença entre aquilo que é garantido (ou imposto) prima facie e aquilo que é garantido (ou imposto) definitivamente". ${ }^{28}$

Silva define o conteúdo essencial dos direitos fundamentais como o resultado da relação entre três variáveis: aquilo que é protegido pelas normas de direitos fundamentais; a relação entre o que é protegido e suas possíveis restrições; e a fundamentação tanto do que é protegido como de suas restrições. ${ }^{29}$ Aquilo que é protegido pelas normas de direitos fundamentais se chama âmbito de proteção. Trata-se do que é protegido prima facie pelo direito fundamental, ou seja,

[...] toda ação, estado ou posição jurídica que possua alguma característica que, isoladamente considerada, faça parte do "âmbito temático" de um determinado direito fundamental, deve ser considerada como abrangida por seu âmbito de proteção, independentemente da consideração de outras variáveis. A definição é propositalmente aberta, já que é justamente essa abertura que caracteriza a amplitude da proteção. Também a resposta individualizada à mesma questão - o que é protegido prima facie? - segue o mesmo caráter aberto. Exemplo: o que é protegido pelo direito à livre manifestação do pensamento (constituição, art. $5^{\circ}$, IV)? Toda e qualquer manifestação de pensamento, não importa o conteúdo (ofensivo ou não), não importa a forma, não importa o local, não importa o dia e o horário. $\mathrm{O}$ mesmo vale para todos os direitos fundamentais. ${ }^{30}$

Quando direitos diferentes entram em rota de colisão, surge a necessidade de restringir o exercício de um ou de ambos. $\mathrm{O}$ autor defende a teoria dos princípios como teoria externa, fundamentando que "ao contrário da teoria interna, que pressupõe a existência de apenas um objeto, o direito e seus limites (imanentes), a teoria externa divide esse objeto em dois: há, em primeiro lugar, o direito em si, e, destacado dele, as suas restrições" ${ }^{31}$. O pesquisador conclui que "é principalmente a partir dessa distinção que se pode chegar ao sopesamento como forma de solução das colisões entre direitos fundamentais e [...] à regra da proporcionalidade, com suas três sub-regras - adequação, necessidade e proporcionalidade em sentido estrito". ${ }^{32}$

Partindo, portando, do pressuposto de que o conteúdo essencial do direito fundamental não sofre limitações diante da efetividade de um direito colidente, uma vez que apenas o seu exercício é restringido, trata-se de uma perspectiva relativista desse conteúdo, que sugere, entre outras teorias - a depender do autor - que: "[...] toda norma de direito fundamental vale apenas e tão somente 
na medida em que ao direito que garanta não seja contraposto um interesse de maior valor" ${ }^{33}$. Isto é, a restrição de um direito fundamental por um dispositivo legal, a fim de proteger bens jurídicos mais importantes, não afeta o conteúdo essencial do direito restringido, mesmo que, em alguns casos individuais, desse direito não reste nada. ${ }^{34}$

É necessário destacar que a decisão do juiz ao restringir um ou outro direito não pode ser feita de forma arbitrária, e sim levando em consideração a devida fundamentação do que é protegido e do que é limitado, pois se trata de uma das variáveis que compõem o fenômeno do conteúdo essencial dos direitos fundamentais.

É claro que um princípio só pode excepcionar a aplicação de outro quando isso for suficientemente fundamentado de um ponto de vista discursivo. Mas efetivamente os discursos de aplicação podem apresentar tal fundamentação. Pelo fato de os princípios não poderem ser contemporaneamente aplicados, não devemos pressupor que a decisão chegue a ferir a integridade do direito. Não é a aplicação contemporânea de todos os princípios que se exige do juiz Hércules, mas a decisão justa. ${ }^{35}$

Para chegar a um resultado minimamente "justo", então, o juiz lança mão da regra da proporcionalidade (ou ponderação) e seus três desdobramentos: adequação, necessidade e proporcionalidade em sentido estrito. $O$ julgador analisa as condições fáticas e jurídicas a fim de sopesar, ou seja, determinar o peso de casa princípio e, consequentemente, de que forma serão protegidos ou limitados os direitos fundamentais em questão.
O vocábulo ponderação tem sido usado para designar, de forma genérica, as diversas operações hermenêuticas consistentes em so- pesar bens, valores, interesses, normas ou argumentos. Em sentido estrito, a ponderação pode ser definida, de forma esquemática, como a técnica de decisão pela qual o operador jurídico contrapesa, a partir de um juízo dialético, os bens e interesses juridicamente protegidos que se mostrem inconciliáveis no caso concreto, visando a determinar qual deles possui maior peso e, assim, identificar a norma jurídica abstrata que há de prevalecer como fundamento da decisão adotada. ${ }^{36}$

Silva esclarece que "o objetivo da aplicação da regra da proporcionalidade, como o próprio nome indica, é fazer com que nenhuma restrição a direitos fundamentais tome dimensões desproporcionais". ${ }^{37}$ Para aferir se a restrição a um direito é proporcional, o julgador leva em conta a adequação do meio utilizado, que tem a ver com a idoneidade do meio para alcançar o fim almejado por ele.

O meio será adequado, na lição de Dimoulis e Martins, ${ }^{38}$ se houver "conexão fundada em hipóteses comprovadas sobre a realidade empírica entre o estado de coisas conseguido pela intervenção e o estado de coisas no qual o propósito puder ser considerado realizado". Assim, "todos os meios empregados 
pelo Estado e que não implicarem essa conexão empiricamente comprovável são considerados desproporcionais e, por via de consequência, inconstitucionais". ${ }^{39}$ Cumpre destacar, de acordo com Silva, que adequado "não é somente o meio com cuja utilização um objetivo é alcançado, mas também o meio com cuja utilização a realização de um objetivo é fomentada, promovida, ainda que o objetivo não seja completamente realizado". ${ }^{40}$

Após a análise da adequação, passa-se à análise da necessidade, que, por sua vez, precede a da proporcionalidade em sentido estrito. "A real importância dessa ordem fica patente quando se tem em mente que a aplicação da regra da proporcionalidade nem sempre implica a análise de todas as suas três sub-regras. Pode-se dizer que tais sub-regras relacionam-se de forma subsidiária entre si" ${ }^{41}$

Dessa forma, não sendo suficiente a observação da adequação do meio, é também vislumbrado pelo juiz se tal intervenção é necessária, isto é, "dentre todos os meios que permitem alcançar os propósitos lícitos, somente o que gravar o direito fundamental com menor intensidade será o necessário. Todos os demais são desnecessários, sendo desproporcionais". ${ }^{42}$ Nas palavras de Silva, "um ato estatal que limita um direito fundamental é somente necessário caso a realização do objetivo perseguido não possa ser promovida, com a mesma intensidade, por meio de outro ato que limite, em menor medida, o direito fundamental atingido". ${ }^{43}$

Por fim, o julgador coloca em equação os ônus e as vantagens advindas da relação entre proteger e limitar os direitos colidentes. É a sub-regra da ponderação propriamente dita, "que consiste em um sopesamento entre a intensidade da restrição ao direito fundamental atingido e a importância da realização do direito fundamental que com ele colide e que fundamenta a adoção da medida restritiva". ${ }^{44}$ Portanto, uma medida será desproporcional não só quando implique a não realização de um direito fundamental ou quando atinja o núcleo essencial de algum direito, mas quando os motivos que fundamentam a adoção da medida não tenham peso suficiente para justificar a restrição ao direito fundamental atingido. ${ }^{45}$

Dessa forma, entende-se proporcional a restrição a um direito que seja adequada, necessária e/ou proporcional em sentido estrito. É preciso analisar, então, de que forma se dá a regra da proporcionalidade na prática.

Silva defende que o método para sopesar direitos deve partir de critérios objetivos. ${ }^{46} \mathrm{~A}$ ideia de objetividade proposta pelo autor se desdobra em duas variáveis: a possibilidade de controle intersubjetivo e a previsibilidade da decisão. Para tanto, essa divisão parte de três aspectos: metodológico, teórico e institucional.

O aspecto metodológico consiste em fundamentar as relações de preferência, "o que implica a fixação de um escalonamento na relação entre a restrição de um direito e realização de outro". ${ }^{47} \mathrm{O}$ aspecto teórico, por sua vez, "consiste na explicitação de pontos de partida teóricos na argumentação jurídica. [...] O problema principal não está relacionado à análise do caso concreto, mas às premissas teóricas de que se parte para solucioná-lo" ${ }^{48}$ 
O autor sugere que sejam indagados, nesse momento, qual é o papel dos direitos fundamentais no ordenamento jurídico e na aplicação do direito em geral e se há direitos fundamentais mais importantes do que outros e por que. ${ }^{49}$

Se se parte, por exemplo, do pressuposto de que, em um Estado Democrático de Direito, a liberdade de expressão tem, ao menos prima facie, uma fundamentalidade maior do que outros direitos, e se essa premissa teórica é fundamentada de forma consistente - o que é perfeitamente possível - há aí um bom começo para um sopesamento e para justificar a decisão no sentido de que alguém pode publicar o que quiser, não importa o conteúdo. [...] A partir dessa premissa teórica, quanto mais livre for o fluxo da comunicação, melhor. ${ }^{50}$

Por fim, o aspecto institucional tem a ver com o respeito a precedentes e o controle social. "Respeito a precedentes pode ser compreendido da seguinte forma: quanto maior for o respeito a decisões judiciais tomadas em casos semelhantes, menor será a liberdade subjetiva do aplicador do direito ao realizar um sopesamento". ${ }^{51}$ Já o controle social tem a ver com o combate às decisões ad hoc, que geram imprevisibilidade e insegurança jurídica.

O doutrinador conclui, portanto, que muito embora o sopesamento seja criticado por sugerir irracionalidade, subjetividade do juiz e insegurança jurídica, trata-se, em verdade, de uma técnica que pode (e deve) se valer da objetividade na interpretação do direito, aumentando a possibilidade de controle intersubjetivo e a possibilidade de previsibilidade das decisões.

Tal discussão é necessária ao presente trabalho tendo em vista tratar-se de direitos fundamentais que constantemente se chocam com outros de relevância equivalente. Ao analisar os recentes julgamentos envolvendo conflitos de direitos fundamentais e da personalidade no âmbito do exercício midiático, é necessário compreender que tais decisões não foram feitas ao acaso e sob uma convicção imotivada do juiz, mas que, talvez, o que tem sido julgado desde 2009, quando da revogação da Lei da Imprensa (Lei 5.250/67), tem criado precedentes, ou seja, fortalecido a previsibilidade das decisões.

\subsection{Análise jurisprudencial}

Analisando os recentes julgados dos tribunais superiores nas lides envolvendo jornalistas ou veículos de comunicação, é possível perceber como a liberdade de expressão e o direito à informação têm sido relativizados diante de outros direitos fundamentais.

Para tanto, foram observadas decisões proferidas pelo Superior Tribunal de Justiça e pelo Supremo Tribunal Federal entre 30 de abril de 2009 e 30 de abril de 2015. A seleção dos julgados ocorreu por meio das ferramentas de livre busca de jurisprudência nos sites do STF e STJ. Utilizando as palavras-chave "jornalismo", "investigação jornalística" e "matéria jornalística", foram 
encontradas 256 decisões. Destas, apenas 65 foram filtradas para análise com base nos seguintes critérios:

- Decisões proferidas apenas por STF e STJ;

- Lides das quais jornalistas ou veículos de comunicação não publicitários ocupassem um dos polos da relação jurídica;

- Exclusão de jurisprudências sobre temas que não envolvessem diretamente o exercício da imprensa em confronto com direitos fundamentais, como as decisões que tratam de registro profissional ou matéria trabalhista;

- Apenas jurisprudências que trouxessem casos de responsabilidade civil e penal, bem como de direito de resposta, isto é, excluindo os julgados de matérias trabalhistas, constitucionais, eleitorais, desportivas e outras.

O período analisado compreende a data em que a Lei de Imprensa foi considerada não recepcionada pelo Supremo Tribunal Federal, em 30 de abril de 2009, terminando em 30 de abril de 2015, tendo em vista que delimitar o lapso de seis anos exatos de julgamentos se mostrou o método mais eficaz em prol da organização e da captação das jurisprudências.

Dessa forma, é possível, desde logo, perceber que entre decisões que se encaixam nos parâmetros definidos na pesquisa, 41 julgados apresentam decisões contemplativas de mérito, enquanto 24 tratam de questões preliminares ou meramente processuais (gráfico 1).

Gráfico 1 - Decisões de mérito

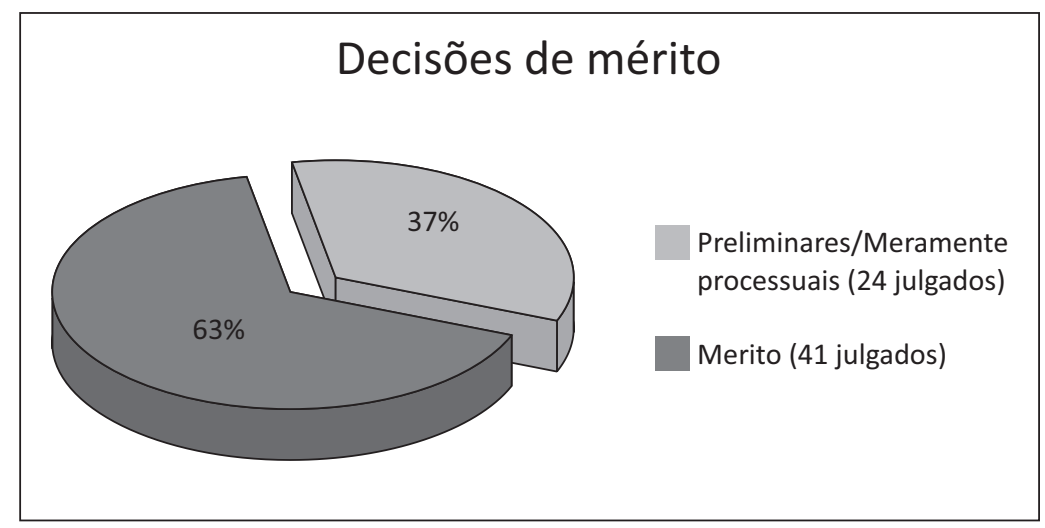

Fonte: elaboração própria.

A análise jurisprudencial, portanto, é feita sobre as 41 decisões que versam sobre o mérito da causa. ${ }^{52} \mathrm{~A}$ metodologia utilizada é a análise quali-quantitativa, descritiva e indutiva. 


\subsubsection{Jornalismo em pauta: o mérito da questão}

A investigação é fase inerente à atividade jornalística. Seja qual for o conteúdo a ser noticiado, é dever dos profissionais de imprensa levar à frente a apuração das informações de forma completa e plural, o mais minuciosamente possível. Quando se trata de temas de visível interesse social, tais como crimes na administração pública, urge que essa investigação seja feita de forma ainda mais responsável, buscando evitar a violação de direitos fundamentais por parte da imprensa.

Analisando as decisões de mérito proferidas pelo Supremo Tribunal Federal e pelo Superior Tribunal de Justiça, pôde-se constatar que a maioria dos julgados, além de ter sido proferida pelo STJ (gráfico 2), é de natureza cível. Gráfico 2 - Decisões por tribunal

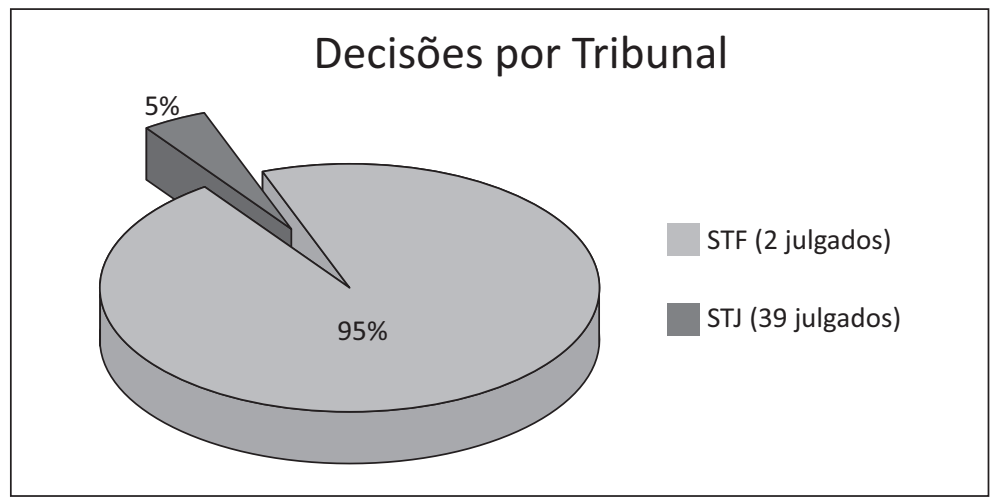

Fonte: elaboração própria.

Das 41 decisões, 40 são relativas à responsabilidade civil, e apenas uma tem a ver com a responsabilidade penal dos jornalistas (gráfico 3).

Gráfico 3 - Decisões por natureza

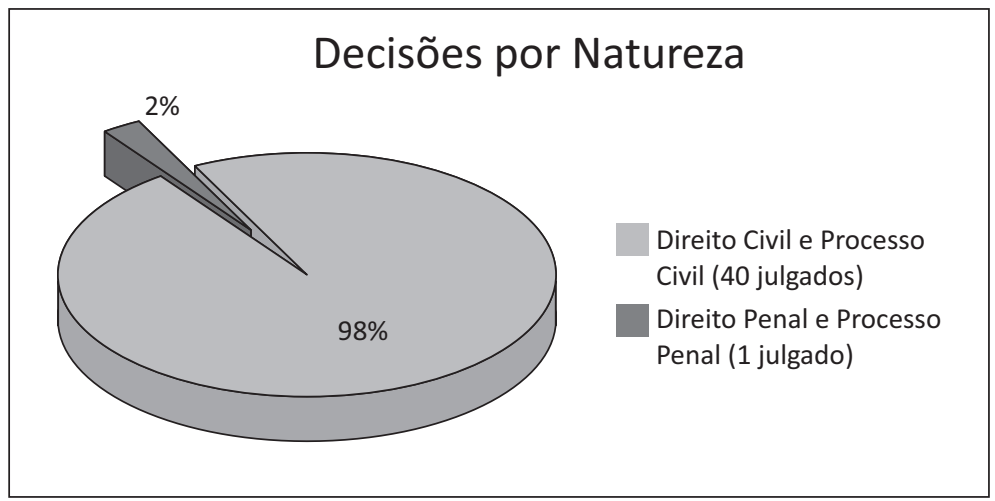

Fonte: elaboração própria. 
As ações civis, por sua vez, versam, em sua maior parte, de indenizações por danos morais, tendo em vista a violação do direito à honra causada por profissionais da mídia e/ou veículos de comunicação. Em segundo lugar, estão as indenizações por violação à imagem e, por fim, sete julgados são relativos aos direitos de resposta, de crítica, ao esquecimento e à privacidade (gráfico 4).

Gráfico 4 - Decisões por assunto

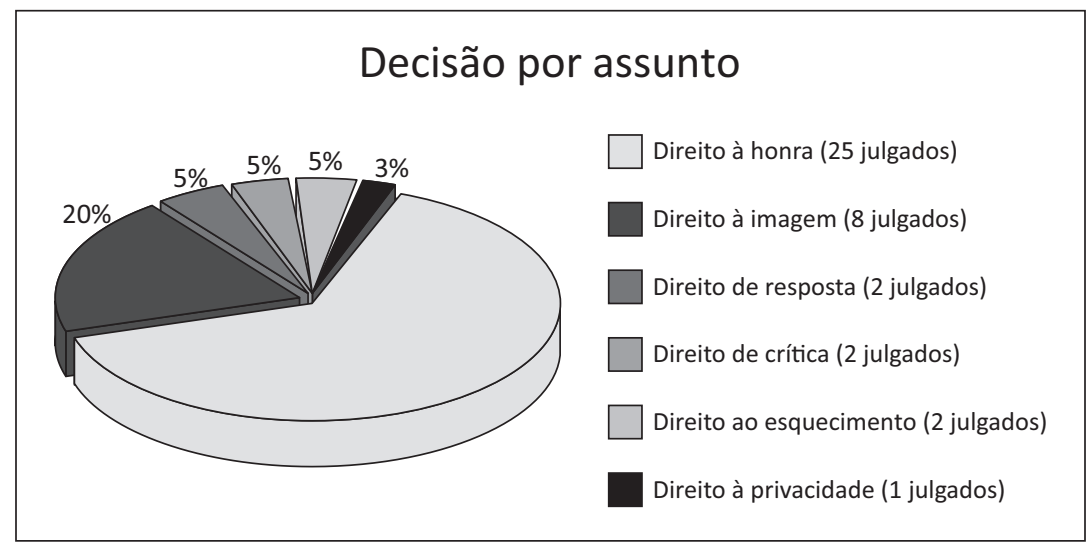

Fonte: elaboração própria.

A partir desse último dado, é possível considerar que, de fato, o direito de resposta teve, entre 2009 e 2015, menor utilização face à possibilidade de 0 ofendido se valer das indenizações pecuniárias.

Os Embargos de Declaração no Agravo de Instrumento n ${ }^{\circ}$ 777.203/PR, proferido em 14 de junho de 2011 pelo STF, julgou a favor do jornal Gazeta do Povo, do Paraná, ao determinar que a simples reprodução de declaração de outrem não justifica o direito de resposta que, no caso, não foi concedido ao ofendido. ${ }^{53}$

No Recurso Ordinário em Mandado de Segurança n ${ }^{\circ}$ 27.549/SP, julgado em 6 de dezembro de 2011 pelo STJ, ${ }^{54}$ a decisão foi desfavorável a Juliano Gasparini, jornalista e responsável legal da Folha de Vinhedo, empresa paulista que havia impetrado o mandado de segurança a fim de evitar a publicação do direito de resposta no veículo. No caso, o jornalista e um vereador haviam conseguido, por meio de gravação clandestina, a acusação do ex-secretário de negócios jurídicos da Prefeitura de Vinhedo-SP contra um juiz e dois promotores, que estariam favorecendo o prefeito em ações judiciais. Após diversas publicações acusando os membros do Judiciário de integrarem uma rede de corrupção e tráfico de influência, foi movido o pleito de resposta contra o jornalista. ${ }^{55} \mathrm{O}$ STJ entendeu que Juliano não demonstrou direito líquido e certo ameaçado, razão pela qual não ter sido possível reformar o acórdão que concedeu o direito de resposta aos ofendidos. 
Quanto aos demais casos, que tratam das indenizações, a colisão de direitos fundamentais se manifesta sobretudo entre a dupla liberdade de expressão e o direito à informação versus os direitos à honra e à imagem.

Das 25 lides envolvendo ofensa à honra, 14 condenam jornalistas e/ou veículos de comunicação ao pagamento de indenizações. Entre elas, destacam-se os casos envolvendo autoridades políticas, como no Resp 1.120.971/RJ, julgado peloSTJ em 28 de fevereiro de $2012 .{ }^{56} \mathrm{O}$ recorrente tratava-se do ex-presidente da República, Fernando Collor de Mello, que buscou em juízo o ressarcimento por danos morais em razão de matéria publicada na revista Veja a qual lhe atribuía a qualidade de "corrupto desvairado". O tribunal fixou o valor da indenização em $\mathrm{R} \$ 500.000,00$, como desestímulo ao cometimento de injúria, tendo em vista que Collor havia sido absolvido da acusação de corrupção, cumprindo a suspensão de direitos políticos e vindo a ser eleito Senador da República.

No REsp 1.374.177/GO, julgado em 5 de setembro de 2013, o STJ decidiu em favor do deputado federal Sandro Mabel, que foi acusado em matéria jornalística de integrar o rol dos "mensaleiros bons de renda". No entanto, conforme consta nos autos, Mabel fora absolvido de qualquer envolvimento no escândalo mensalão pelo Conselho de Ética da Câmara dos Deputados em novembro de 2005, quase um ano antes da notícia veiculada em 2006. Não foi, tampouco, denunciado pelo Ministério Público. Diante da ofensa à honra do deputado, o Ministro Luis Felipe Salomão sopesou os direitos fundamentais da seguinte forma:

O direito à informação não elimina as garantias individuais, porém encontra nelas os seus limites, devendo atentar ao dever de veracidade. Tal dever, ao qual estão vinculados os órgãos de imprensa não deve consubstanciar-se dogma absoluto, ou condição peremptoriamente necessária à liberdade de imprensa, mas um compromisso ético com a informação verossímil, o que pode, eventualmente, abarcar informações não totalmente precisas. Não se exigindo, contudo, prova inequívoca da má-fé da publicação. [...] Assim, correto o acórdão estadual quando condenou o jornal, concluindo que a liberdade de informação foi extrapolada, desbordando do dever de informar e noticiar fatos ao adentrar no campo da inviolabilidade da honra do Deputado, incluindo-o como beneficiário de vantagem indevida, mesmo sabedor que este fora absolvido pelo Conselho de Ética da Câmara dos Deputados. ${ }^{57}$

O abuso do direito de informar também restou configurado na hipótese de publicação do nome e da imagem de adolescente morto, atribuindo-lhe autoria de ato infracional, violando o princípio da proteção integral da criança e do adolescente (artigos 143 e 247 do Estatuto da Criança e do Adolescente), julgada no AgRg no REsp 1.354.696/PR, ${ }^{58}$ de 23 de outubro de 2014.

No REsp 713.202/RS, o STJ destacou o exercício irregular da imprensa no caso em que foi reproduzido no jornal gaúcho Diário Popular entrevista concedida pela ex-companheira do futebolista e comentarista esportivo Paulo 
Roberto Falcão, na qual são proferidas declarações ofensivas à honra dele e imputada, falsamente, conduta criminosa. Assim consta na decisão final, de $1^{\circ}$ de outubro de 2009:

Ônus de um mínimo de diligência investigativa não observado pelo órgão de imprensa. Ausência de interesse social em fatos íntimos da vida privada da pessoa, ainda que goze de notoriedade. Credibilidade do jornal que permitiu a ampliação e perpetuação da violação à honorabilidade do autor. Desbordamento do direito/ dever de informar. Conduta ilícita. Dano moral configurado. ${ }^{59}$

Tratando-se das indenizações por violação à honra - e, da mesma forma, quanto à violação à imagem -, o valor atribuído ao pagamento por parte dos jornalistas e dos veículos de comunicação não é uniforme entre as condenações. Levando em conta fatores como a capacidade econômica do ofensor e do ofendido, a gravidade do ato, o alcance da ofensa e a extensão do dano, os valores fixados para ressarcimento variam de $\mathrm{R} \$ 5.000,00$ a $\mathrm{R} \$ 150.000,00$ - além dos $\mathrm{R} \$ 500.000,00$ no caso Collor -, o que elucida o fato de estar na mão dos julgadores a tarefa de equalizar a reparação de danos pela regra da proporcionalidade. Diferentemente dos valores a serem pagos pelo ofensor previstos na Lei de Imprensa (Lei 5.250/67), que não poderiam ultrapassar duzentos salários mínimos (art. 52), a importância fixada em juízo atualmente não tem limites máximos nem mínimos.

Os 11 casos absolvendo a mídia da condenação pecuniária contra suposta violação à honra destacam, sobretudo, o agir com responsabilidade e o não abuso do direito de informar. A ausência de cunho ofensivo e de grave ofensa à honra da vítima são motivos para o não reconhecimento do dever de indenizar, como no Agravo de Instrumento ${ }^{\circ}{ }^{1}$ 1.161.687/SP, julgado em 30 de março de 2011 pelo $\mathrm{STJ}^{60}$. O tribunal, no mesmo sentido, entendeu pela improcedência do REsp $\mathrm{n}^{\mathrm{O}}$ 1.330.028/DF, envolvendo Fábio Luis Lula da Silva, filho do ex-presidente Lula, uma vez que a responsabilidade civil por danos morais exsurge quando a matéria divulgada tem a intenção de injuriar, difamar ou caluniar terceiro, o que não ocorreu no caso, pois a reportagem apenas afirmava que "Lulinha" havia adquirido uma mansão. Nas palavras do Ministro Relator Ricardo Villas Bôas Cueva,

As instâncias de origem, soberanas na análise das circunstâncias fáticas da causa, decidiram pela improcedência do pedido indenizatório, firmes no entendimento de que a matéria publicada era de cunho meramente investigativo, que a alcunha já era utilizada pela mídia e que a notícia veiculada encontrava lastro em matérias já anteriormente publicadas por outros veículos de comunicação, revestindo-se, ainda, de interesse público, sem nenhum sensacionalismo ou intromissão na privacidade do autor, não gerando, portanto, direito à indenização. ${ }^{61}$

O interesse público é suscitado em outras decisões do STJ, como no REsp 1.268.233/DF, julgado em 15 de março de 2012, o qual elucidou que a repor- 
tagem tratando de assunto notório e não voltada à ofensa da honra de terceiros reflete o exercício regular do direito de informar do veículo de imprensa, não configurando hipótese indenizável. ${ }^{62}$

O direito à informação prevaleceu no julgamento do REsp 1.269.841/SP, de 17 de outubro de 2013. A Ministra Nancy Andrighi destacou na decisão a não potencialidade ofensiva de matéria jornalística que apontou possível envolvimento ilícito de magistrado com traficantes de drogas e seu consequente afastamento do cargo. A jurista ressaltou que a divulgação de informações deve ser célere e eficaz, satisfazendo verdadeiro interesse público:

A liberdade de informação deve estar atenta ao dever de veracidade, pois a falsidade dos dados divulgados manipula em vez de formar a opinião pública, bem como ao interesse público, pois nem toda informação verdadeira é relevante para o convívio em sociedade. [...] A honra e imagem dos cidadãos não são violados quando se divulgam informações verdadeiras e fidedignas a seu respeito e que, além disso, são do interesse público. [...] O veículo de comunicação exime-se de culpa quando busca fontes fidedignas, quando exerce atividade investigativa, ouve as diversas partes interessadas e afasta quaisquer dúvidas sérias quanto à veracidade do que divulgará. ${ }^{63}$

O segundo maior número de lides que chegaram aos tribunais superiores trata do direito à imagem. Dos 8 casos, 5 condenam jornalistas e/ou veículos de comunicação pela violação a esse direito. As decisões condenatórias destacam, sobretudo, que "a ofensa ao direito à imagem materializa-se com a mera utilização da imagem sem autorização, ainda que não tenha caráter vexatório ou que não viole a honra ou a intimidade da pessoa, e desde que o conteúdo exibido seja capaz de individualizar o ofendido", ${ }^{64}$ conforme dispõe a Súmula 403 do STJ ${ }^{65}$ Assim é o entendimento no AgRg 1.345.989/SP, no REsp 1.005.278/SE e no REsp 794.586/RJ:

Na hipótese, não obstante o direito de informação da empresa de comunicação e o perceptível caráter de interesse público do quadro retratado no programa televisivo, está clara a ofensa ao direito à imagem do recorrido, pela utilização econômica desta, sem a proteção dos recursos de editoração de voz e de imagem para ocultar a pessoa, evitando-se a perfeita identificação do entrevistado, à revelia de autorização expressa deste, o que constitui ato ilícito indenizável. [...] A obrigação de reparação decorre do próprio uso indevido do direito personalíssimo, não sendo devido exigir-se a prova da existência de prejuízo ou dano. O dano é a própria utilização indevida da imagem. ${ }^{66}$

Por outro lado, os julgados em que o direito à informação prevalece sobre a imagem ressaltam a relativização desse direito quando se tratar de pessoas públicas. No REsp 1.021.688/RJ, julgado em 23 de junho de 2009, a decisão destacou que a exposição de "lado negativo" da figura pública causou simples incômodo ou desconforto, não havendo o que indenizar. ${ }^{67}$ 
Já no REsp 801.109/DF, julgado em 12 de julho de 2012, foram considerados fatores relevantes para o sopesamento entre a liberdade de expressão e o direito à imagem, pois "tratando-se de imagem de multidão, de pessoa famosa ou ocupante de cargo público, deve ser ponderado se, dadas as circunstâncias, a exposição da imagem é ofensiva à privacidade ou à intimidade do retratado, $\mathrm{o}$ que poderia ensejar algum dano patrimonial ou extrapatrimonial”, já que, nessas hipóteses, em regra, há presunção de consentimento do uso da imagem, desde que preservada a vida privada. No caso de ocupante de cargo público, de notória importância social, "fica mais restrito o âmbito de reconhecimento do dano à imagem e sua extensão, mormente quando utilizada a fotografia para ilustrar matéria jornalística pertinente, sem invasão da vida privada do retratado" ${ }^{68} \mathrm{~A}$ decisão ainda ressalta que:

A análise relativa à ocorrência de abuso no exercício da liberdade de expressão jornalística a ensejar reparação civil por dano moral a direitos da personalidade depende do exame de cada caso concreto, máxime quando atingida pessoa investida de autoridade pública, pois, em tese, sopesados os valores em conflito, mostra-se recomendável que se dê prevalência à liberdade de informação e de crítica, como preço que se paga por viver num Estado Democrático. ${ }^{69}$

Quanto aos direitos de crítica e ao esquecimento, os tribunais superiores têm entendido prioritariamente em favor dos profissionais da mídia. Dos quatro julgados, apenas um condenou veículo de comunicação ao pagamento de danos morais - no valor de $\mathrm{R} \$ 50.000,00$ - pela apresentação de documentário sobre a Chacina da Candelária 13 anos após o ocorrido. No filme, foram divulgados o nome e a imagem de suspeito indiciado à época dos crimes, que foi absolvido posteriormente. A decisão do REsp 1.334.097/RJ, de 28 de maio de 2013, ressaltou que a publicação do fato histórico, mesmo que fidedigna, reacendeu a desconfiança e o ódio da sociedade, ferindo a paz, o anonimato e a privacidade do ofendido. ${ }^{70}$

Entre os julgados que favoreceram o direito à informação, destaque-se o AgRg no AgIn 705.630/SC, de 22 de março de 2011. O Ministro do STF e relator do caso, Celso de Mello, ao sopesar os direitos fundamentais em questão, ressaltou que a liberdade de imprensa, enquanto projeção das liberdades de comunicação e de manifestação do pensamento, reveste-se de conteúdos, como o direito de informar, o direito de buscar a informação, o direito de opinar e o direito de criticar. A crítica jornalística, portanto, seria amparada pelo interesse social e legitimada de qualificação constitucional e, dirigida às pessoas públicas, "por mais dura e veemente que possa ser, deixa de sofrer, quanto ao seu concreto exercício, as limitações externas que ordinariamente resultam dos direitos de personalidade", isto é, "a liberdade de crítica qualifica-se como verdadeira excludente anímica, apta a afastar o intuito doloso de ofender". ${ }^{71}$

Por fim, o único julgado envolvendo a responsabilidade penal do jornalista trata de habeas corpus para trancamento de ação contra profissional da imprensa 
que teria praticado crime contra a honra em face de promotora de justiça. $\mathrm{O}$ HC 198.402/BA foi julgado em 22 de novembro de 2011 pelo STJ, que concedeu a ordem em favor do jornalista, denunciado por difamação. Segundo o entendimento da Ministra Laurita Vaz, as condutas imputadas ao profissional não configuram crime, havendo ausência de justa causa para tanto. Ao declarar a atipicidade da conduta do paciente, a Ministra destacou que:

O denunciado agiu dentro do legítimo direito à cidadania, ao exigir das autoridades públicas municipais as providências cabíveis para os problemas publicados. Atuou com o claro intuito de buscar proteção para um interesse transindividual, sem qualquer elemento volitivo que se permita concluir que tinha intenção de macular a honra da funcionária pública. ${ }^{72}$

Diante da análise dos julgados, além de perceber que a maioria absoluta das ações envolvendo a mídia são de natureza cível, e que as indenizações prevalecem sobre o direito de resposta, é possível visualizar a ausência de julgamentos que envolvam acusações contra jornalistas pela prática dos crimes de calúnia e injúria, bem como de falsa identidade e interceptação telefônica. Esse fato exige, portanto, uma reflexão: os métodos utilizados pelos jornalistas têm respeitado os preceitos do Código de Ética profissional e as vedações do Código Penal e das leis específicas tais como a Lei de Interceptação Telefônica (Lei 9.296/96) - ou as ações em que há, de fato, denúncias contra jornalistas pela prática desses crimes não cumprem os requisitos de admissibilidade necessários para serem apreciados pelos tribunais superiores, conforme a vedação das Súmulas 7 do STJ ${ }^{73}$ e 279 do STF? ${ }^{74}$

Mesmo sem esse questionamento ser o foco desta pesquisa, e ainda que não haja uma resposta certa para ele, é necessário fazê-lo, haja vista que, se for considerada a primeira hipótese, pode-se cogitar a possibilidade de um exercício midiático mais próximo da responsabilidade social que a imprensa impõe, uma vez que a análise jurisprudencial mostrou não haver unanimidade no embate entre os direitos fundamentais em questão.

\section{CONCLUSÕES}

Esta pesquisa teve como objetivo analisar os limites da liberdade de expressão e do direito à informação em face do conflito com outros direitos fundamentais, avaliando, de forma quali-quantitativa, descritiva e indutiva, o entendimento jurisprudencial proferido pelo Supremo Tribunal Federal e pelo Superior Tribunal de Justiça entre 30 de abril de 2009 (data da não recepção da Lei de Imprensa - Lei n 5.250/67) e 30 de abril de 2015.

Com base em 41 decisões de mérito analisadas, procurou-se esclarecer quais dos direitos em conflito têm ou não prevalecido nos casos concretos, buscando chegar uma resposta mais próxima da realidade quanto aos reais limites da atuação jornalística e compreender se o que tem sido julgado, desde 2009 tem criado precedentes, ou seja, fortalecido a previsibilidade das decisões. 
De um modo geral, as lides envolvendo a liberdade de expressão e o direito à informação versus o direito à honra, à imagem e a outros direitos fundamentais, nas decisões de mérito proferidas pelo STF e pelo STJ, entre 2009 e 2015, revelaram, estatisticamente, que o sopesamento entre tais direitos tem acontecido de forma equilibrada, uma vez que a margem de diferença entre os casos em que prevalecem os direitos à honra, à imagem, à crítica, ao esquecimento, à privacidade e o direito de resposta sobre o direito de informar - surgindo, consequentemente, o dever de indenizar por parte da imprensa - não é larga a ponto de se conseguir visualizar uma posição tendente dos tribunais.

Em termos numéricos, das 40 decisões cíveis, 21 condenam a imprensa à indenização por danos morais e materiais em razão de ofensa a direitos fundamentais de terceiros - destacando a vedação dos jornalistas de atuarem de forma indiscriminada, proibindo-os e responsabilizando-os pela ofensa a direitos fundamentais -, enquanto 19 julgados absolvem os jornalistas e os veículos de comunicação em litígio, prevalecendo, nesses casos, a liberdade de expressão e o direito à informação, ressaltando tais princípios como elementos essenciais para suprir o interesse coletivo (gráfico 5). Além disso, o único julgado envolvendo a responsabilidade penal dos jornalistas tratou de habeas corpus para trancamento de ação que foi concedido em favor do profissional da imprensa.

Pela pequena margem de diferença entre as condenatórias e as absolutórias, não se pode concluir que há uma posição tendente dos tribunais, isto é, não se percebeu um fortalecimento da previsibilidade das decisões em nenhum dos dois sentidos especificamente.

Gráfico 5 - Dever de indenizar (Decisões cíveis)

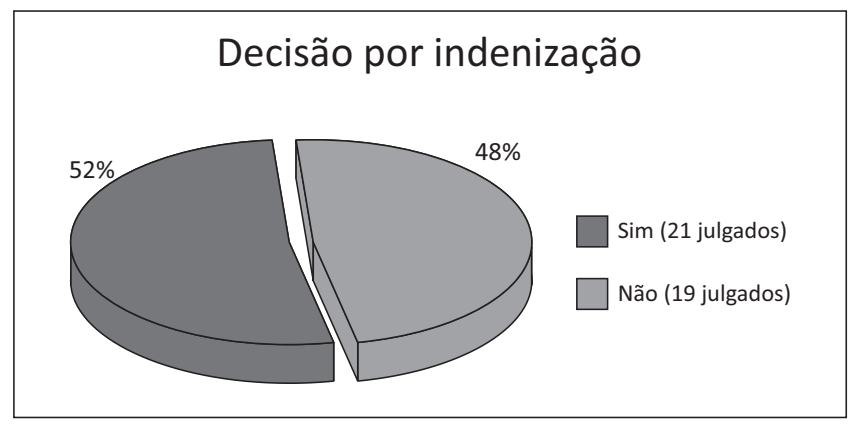

Fonte: elaboração própria.

O equilíbrio dos resultados do sopesamento nos casos concretos se mostra salutar, uma vez que temerária seria a limitação indiscriminada da liberdade de expressão e do direito à informação em detrimento de outros direitos fundamentais, o que submeteria os profissionais da mídia a uma restrita atuação, prejudicando os propósitos da atividade jornalística, como a busca por uma sociedade mais democrática. Por outro lado, a garantia absoluta da liberdade de expressão e do 
direito à informação em face dos demais direitos fundamentais acarretaria toda sorte de publicações e veiculações cujo conteúdo se distanciaria da função social que o jornalismo se propõe a ter: a liberdade desmesurada poderia fomentar a corrida pela audiência, o abuso do sensacionalismo e, por consequência, o aumento na violação de direitos fundamentais de outrem, em um círculo vicioso.

Os tribunais superiores seguem um entendimento que se mostra acertado, não adotando uma posição tendenciosa em favor de nenhum dos direitos fundamentais especificamente, mas limitando, fundamentadamente - seja a favor do interesse público, seja contra o abuso no exercício midiático -, a liberdade de expressão e o direito à informação em face de outros princípios a depender do caso concreto.

O que se pode concluir com essa análise é que, de fato, nenhum direito é absoluto, e a Constituição Federal garante a proteção de todos os direitos fundamentais de forma ampla, devendo cada caso ser considerado individualmente, o que eleva aos julgadores a tarefa - e a responsabilidade, no sentido lato do termo - de aferir em que situações os jornalistas terão mais liberdade para poder exercer a atividade e em quais esses profissionais terão o exercício do direito à informação limitado face à prevalência, naquela situação fática, de outros direitos fundamentais.

O jornalismo e sua proposta de trazer à tona fatos de importância social e/ou de difícil acesso ao público tanto pode quanto se deve valer de sua responsabilidade na busca coletiva de mais justiça, sobretudo em se tratando de casos envolvendo políticos, magistrados e particulares que atentem contra a dignidade humana e os interesses sociais. Os profissionais da mídia não podem, entretanto, agir irresponsavelmente, ferindo direitos fundamentais de outrem, em nome de uma função social.

Aos jornalistas cabe o dever de buscar, com base na ética, na legalidade e no respeito à dignidade humana e aos demais direitos fundamentais, a informação justa, correta e plural e lançá-la ao público, com vistas à concretização de suas principais finalidades: informar, orientar e proporcionar uma sociedade mais democrática.

\section{REFERÊNCIAS}

ALEXY, Robert. Constitucionalismo discursivo. Tradução de Luís Afonso Heck. Porto Alegre: Livraria do Advogado, 2007.

ASSEMBLEIA GERAL DAS NAÇÕES UNIDAS. Declaração Universal dos Direitos Humanos. Disponível em: < http://www.dudh.org.br/wp-content/ uploads/2014/12/dudh.pdf>. Acesso em: 13 mar. 2015.

AVOLIO, Luiz Francisco Torquato. Gravações clandestinas e ambientais no processo civil: as provas imorais. Revista dos tribunais, São Paulo, ano 92, v. 818, p. 47-64, dez. 2003. 
BÔAVIAGEM, Aurélio Agostinho. Responsabilidade Civil da Imprensa. Revista Duc In Altum - Caderno de Direito, Recife, v. 3, n. 3, p. 133- 146, jan/jun. 2011.

BONAVIDES, Paulo. Curso de Direito Constitucional. 15. ed. São Paulo: Malheiros, 2004.

CARVALHO, Luis Gustavo Grandinetti Castanho de. Responsabilidade civil dos meios de comunicação. Revista de direito do consumidor, São Paulo, ano 12, v. 47, p. 153-162, jul./set. 2003.

CHEHAB, Gustavo Carvalho. O direito ao esquecimento na sociedade da informação. Revista dos tribunais, São Paulo, ano 104, v. 952, p. 85-119, fev. 2015.

DIAS, José de Aguiar. Da responsabilidade civil. 2. ed. Rio de Janeiro: Forense, 1950. v. 2.

DIMOULIS, Dimitri; MARTINS, Leonardo. Teoria Geral dos Direitos Fundamentais. São Paulo: Atlas, 2012.

FEDERAÇÃO NACIONAL DOS JORNALISTAS (FENAJ). Código de Ética dos Jornalistas Brasileiros. Disponível em: < http://www.fenaj.org.br/ federacao/cometica/código_de_etica_dos_jornalistas_brasileiros.pdf $>$. Acesso em: 13 maio 2015.

GALUPPO, Marcelo Campos. Os princípios jurídicos no Estado Democrático de Direito: Ensaio sobre o seu modo de aplicação. Revista de Informação Legislativa, Brasília, v. 36, n. 143, p.191-209, jul./set. 1999.

GÓIS, Veruska Sayonara de. O direito à informação jornalística. São Paulo: Intermeios, 2012.

LOPES, Ana Maria D'Ávila. Hierarquização dos direitos fundamentais?. Revista de Direito Constitucional e Internacional, São Paulo, v. 9, n. 34. p. 168-183, 2001.

MORAES, Maria Celina Bodin de. Danos à pessoa humana: uma leitura civil-constitucional dos danos morais. Rio de Janeiro: Renovar, 2003.

MOREIRA, Alexandre Magno Fernandes. Os Crimes contra a honra como um atentado à liberdade de expressão. Revista Jurídica Consulex, Distrito Federal, v. 11, n. 258, p. 40-43, 15 out. 2007.

OLIVEIRA, Caio Cezar Maia de; FALLEIROS, Carolina Teodoro; MENDES, João Múcio Amado. O direito de resposta e a necessidade de regulamentação adequada no Brasil. Revista de direito das comunicações, São Paulo, v. 3, n. 5 , p. 113-186, jan./jun. 2012.

PEREIRA, Jane Reis Gonçalves. Interpretação constitucional e direitos fundamentais. Rio de Janeiro: Renovar, 2006.

RONCAGLIA, Daniel. Judiciário, imprensa e políticos tiram a paz de Vinhedo. Consultor Jurídico. Disponível em: <http://www.conjur.com.br/2007-jul-28/ judiciario_imprensa_politicos_tiram_paz_vinhedo>. Acesso em: 7 jul. 2015. 
SAKAE, Lucia Reiko. A responsabilidade penal da pessoa jurídica. Cadernos de Pós-Graduação em Direito Político e Econômico, São Paulo, v. 4, n. 1, p. 45-57, 2004.

\section{SCHREIBER, Anderson. Direitos da personalidade. São Paulo: Atlas, 2011.}

SILVA, Virgílio Afonso da. O conteúdo essencial dos direitos fundamentais e a eficácia das normas constitucionais. Revista de Direito do Estado, Rio de Janeiro, v. 4, p. 23-51, 2006.

. O proporcional e o razoável. Revista dos tribunais, São Paulo, ano 91, v. 798, p. 23-50, abr. 2002.

. Ponderação e objetividade na interpretação constitucional. In: MACEDO JR., Ronaldo Porto; BARBIERI, Catarina Helena Cortada (Org.). Direito e interpretação: racionalidades e instituições. São Paulo: Direito GV/Saraiva, 2011. p. 363-380.

. Princípios e regras: mitos e equívocos acerca de uma distinção. Revista Latino-Americana de Estudos Constitucionais, Belo Horizonte, v. 1, p. 607630, 2003.

1 ASSEMBLEIA GERAL DAS NAÇÕES UNIDAS. Declaração Universal dos Direitos Humanos. Disponível em: < http://www.dudh.org.br/wp-content/uploads/2014/12/dudh.pdf>. Acesso em: 13 mar. 2015.

2 BONAVIDES, Paulo. Curso de Direito Constitucional. 15. ed. São Paulo: Malheiros, 2004. p. 571.

3 BRASIL. Decreto $n^{\circ} 678$, de 6 de novembro de 1992. Promulga a Convenção Americana sobre Direitos Humanos (Pacto de São José da Costa Rica), de 22 de novembro de 1969. Presidência da República. Disponível em: <http://www.planalto.gov.br/ccivil_03/decreto/D0678.htm>. Acesso em: 15 maio 2015.

4 GÓIS, Veruska Sayonara de. O direito à informação jornalística. São Paulo: Intermeios, 2012. p.24.

5 FEDERAÇÃO NACIONAL DOS JORNALISTAS (FENAJ). Código de Ética dos Jornalistas Brasileiros. Disponível em: <http://www.fenaj.org.br/federacao/cometica/codigo_de_etica_dos_jornalistas_brasileiros.pdf $>$. Acesso em: 13 maio 2015.

6 "Art. $6^{\circ}$ É dever do jornalista: [...] VIII - respeitar o direito à intimidade, à privacidade, à honra e à imagem do cidadão" (FEDERAÇÃO NACIONAL DOS JORNALISTAS (FENAJ). Código de Ética dos Jornalistas Brasileiros.Disponível em: < http://www.fenaj.org.br/federacao/cometica/codigo_de_etica_dos_jornalistas_brasileiros.pdf $>$. Acesso em: 13 maio 2015.

7 Considerando o aspecto do jornalista como profissional liberal, conforme dispõe o $\S 4^{\circ}$ do artigo 14 do Código de Defesa do Consumidor: "Art. 14. [...] § $4^{\circ} \mathrm{A}$ responsabilidade pessoal dos profissionais liberais será apurada mediante a verificação de culpa".

8 Superior Tribunal de Justiça. Súmula n 37 . São cumuláveis as indenizações por dano material e dano moral oriundos do mesmo fato.

9 Schreiber critica o entendimento difundido na doutrina e na jurisprudência pátrias segundo o qual o dano moral consistiria em dor, vexame, sofrimento ou humilhação, argumentando que tal entendimento "tem a flagrante desvantagem de deixar a configuração do dano moral ao sabor de emoções subjetivas da vítima". Por essa razão, o autor defende o dano moral como "lesão a um atributo da personalidade humana" (SCHREIBER, Anderson. Direitos da personalidade. São Paulo: Atlas, 2011, p.16. A V Jornada de Direito Civil sedimentou entendimento, no enunciado 445, no sentido de que "Art. 927: O dano moral indenizável não pressupõe necessariamente a verificação de sentimentos humanos desagradáveis como dor ou sofrimento".

10 MORAES, Maria Celina Bodin de. Danos à pessoa humana: uma leitura civil-constitucional dos danos morais. Rio de Janeiro: Renovar, 2003. p. 87-117.

11 Ibid., p.117.

12 DIAS, José de Aguiar. Da responsabilidade civil. 2. ed. Rio de Janeiro: Forense, 1950, v. 2, p. 318-319. 
13 MOREIRA, Alexandre Magno Fernandes. Os Crimes contra a honra como um atentado à liberdade de expressão. Revista Jurídica Consulex, Distrito Federal, ano 11, n. 258, p. 40-43, 15 out. 2007.

14 CARVALHO, Luis Gustavo Grandinetti Castanho de. Responsabilidade civil dos meios de comunicação. Revista de direito do consumidor, São Paulo, ano 12, v. 47, p. 157, jul./set. 2003.

15 "O não reconhecimento da responsabilização penal da pessoa jurídica é defendido com fundamento na falta de capacidade de ação e de culpabilidade, considerando-as como características próprias dos seres humanos e não de um ente abstrato" (SAKAE, Lucia Reiko. A responsabilidade penal da pessoa jurídica. Cadernos de Pós-Graduação em Direito Político e Econômico,São Paulo, v. 4, n. 1, p. 49, 2004.

16 A responsabilização de pessoas jurídicas para os crimes ambientais é uma exceção prevista constitucionalmente, nos termos dos artigos $173, \S 5^{\circ}$ e $225, \S 3^{\circ}$. Também está prevista na legislação infraconstitucional (Art. $3^{\circ}$, Lei 9.605/98).

17 AVOLIO, Luiz Francisco Torquato. Gravações clandestinas e ambientais no processo civil: as provas imorais. Revista dos tribunais, São Paulo, ano 92, v. 818, p. 50, dez. 2003.

18 A doutrina penalista costuma classificar a interceptação conforme se realize por vias telemáticas ou entre presentes. As formas de interceptação podem ser elencadas como: interceptação telefônica em sentido estrito (também conhecida como grampo telefônico, consiste no registro da conversa efetuada por terceiro sem o consentimento dos interlocutores); escuta telefônica (captação da conversa com o consentimento de apenas um dos interlocutores); interceptação ambiental (registro da conversa entre presentes efetuada por terceiro sem o consentimento dos interlocutores); escuta ambiental (registro da conversa entre presentes por um dos interlocutores sem o conhecimento do outro); gravação clandestina (registro da conversa por um dos interlocutores via telefone sem o conhecimento do outro). (AVOLIO, Luiz Francisco Torquato. Gravações clandestinas e ambientais no processo civil: as provas imorais. Revista dos tribunais, São Paulo, ano 92, v. 818, p. 49, dez. 2003.

19 BÔAVIAGEM, Aurélio Agostinho. Responsabilidade Civil da Imprensa. Revista Duc In Altum - Caderno de Direito, vol. 3, no 3, p. 144-145, jan-jun. 2011,

20 BRASIL. Lei $\mathbf{n}^{\circ} \mathbf{1 3 . 1 8 8}$, de 11 de novembro de 2015. Dispõe sobre o direito de resposta ou retificação do ofendido em matéria divulgada, publicada ou transmitida por veículo de comunicação social. Presidência da República. Disponível em: <http://www.planalto.gov.br/ccivil_03/_Ato2015-2018/2015/ Lei/L13188.htm>. Acesso em: 12 mar. 2016.

21 OLIVEIRA, Caio Cezar Maia de; FALlEIROS, Carolina Teodoro; MENDES, João Múcio Amado. $\mathrm{O}$ direito de resposta e a necessidade de regulamentação adequada no Brasil. Revista de direito das comunicações, São Paulo, v. 3, n. 5, p. 134, jan./jun. 2012.

22 CHEHAB, Gustavo Carvalho. O direito ao esquecimento na sociedade da informação. Revista dos tribunais, São Paulo, ano 104, v. 952, p. 90, fev. 2015.

23 SCHREIBER, Anderson. Direitos da personalidade. São Paulo: Atlas, 2011, p.79-80.

24 SILVA, Virgílio Afonso da. Princípios e regras: mitos e equívocos acerca de uma distinção. Revista Latino-Americana de Estudos Constitucionais, Belo Horizonte, v. 1, p. 618, 2003.

25 Neste trabalho, adotou-se o posicionamento de Robert Alexy e Virgílio Afonso da Silva quanto à teoria dos direitos fundamentais. Será considerada, então, que se tratam, em sua maior parte, de princípios cuja aplicação ocorre de forma gradativa a partir da regra da proporcionalidade.

$26 \mathrm{O}$ doutrinador faz o contraponto dos princípios com as regras, cuja diferença reside no fato de estas garantirem "direitos (ou impõem-se deveres) definitivos, ao passo que, no caso dos princípios, são garantidos direitos (ou são impostos deveres) prima facie. Isso significa que, se um direito é garantido por uma norma que tenha a estrutura de uma regra, esse direito é definitivo e deverá ser realizado totalmente, caso a regra seja aplicável ao caso concreto", comportando exceções (SILVA, Virgílio Afonso da. O conteúdo essencial dos direitos fundamentais e a eficácia das normas constitucionais. Revista de Direito do Estado, Rio de Janeiro, v. 4, p. 27, 2006.

27 Ibid., p. 27.

$28,, \quad$,

29 Ibid., p. 24.

30 Ibid., p. 34-35 (grifos do autor).

31 Ibid., p. 38-39 (grifos do autor).

32 Ibid., p. 39.

33 Ibid., p. 42.

34 Ibid., p. 42. 
35 GALUPPO, Marcelo Campos. Os princípios jurídicos no Estado Democrático de Direito: Ensaio sobre o seu modo de aplicação. Revista de Informação Legislativa. Brasília, Ano 36, n. 143, p.199, jul/set. 1999.

36 PEREIRA, Jane Reis Gonçalves. Interpretação constitucional e direitos fundamentais. Rio de Janeiro: Renovar, 2006. p. 200-201.

37 SILVA, Virgílio Afonso da. O proporcional e o razoável. Revista dos tribunais, São Paulo, ano 91, v. 798, p. 24, abr. 2002.

38 DIMOULIS, Dimitri; MARTINS, Leonardo. Teoria Geral dos Direitos Fundamentais. São Paulo: Atlas, 2012. p. 194

39 Ibid., p. 194.

40 SILVA, Virgílio Afonso da., op. cit., p. 36.

41 Ibid., p. 34 (grifos do autor).

42 DIMOULIS, Dimitri; MARTINS, Leonardo. Teoria Geral dos Direitos Fundamentais. São Paulo: Atlas, 2012. p. 202.

43 SILVA, Virgílio Afonso da., op. cit., p. 38.

44 Ibid., p. 40.

45 Ibid., p. 41.

$46 \mathrm{O}$ autor vem destacar a objetividade diante da desconfiança existente acerca do sopesamento. Assim discorre Lopes: "Atualmente, o método sugerido pelo setor da doutrina que admite a dimensão axiológica dos direitos fundamentais é o da ponderação de bens, o qual não é isento de críticas, pois argumenta-se que não constitui um método racional por sujeitar-se ao arbítrio de quem o realiza, provocando o surgimento de um claro subjetivismo e decisionismo jurisprudencial. Talvez a solução contra um modelo arbitrário de ponderação fosse o estabelecimento de um modelo, não de decisão, mas de fundamentação, baseada não em processos psíquicos, mas racionais" (LOPES, Ana Maria D’Ávila. Hierarquização dos direitos fundamentais?. Revista de Direito Constitucional e Internacional, São Paulo, v. 9, n. 34. p. 169-170, 2001.

47 SILVA, Virgílio Afonso da. Ponderação e objetividade na interpretação constitucional. In: MACEDO JR., Ronaldo Porto; BARBIERI, Catarina Helena Cortada (Org.). Direito e interpretação: racionalidades e instituições. São Paulo: Direito GV/Saraiva, 2011. p.368.

48 Ibid., p. 372.

49 Ibid., p. 373.

50 Ibid., p. 374

51 Ibid., p. 376.

52 A análise quali-quantitativa é feita sobre os seguintes julgados: REsp 1.120.971/RJ; REsp 1.374.177/ GO; AgRg no REsp 1.354.696/PR; REsp 713.202/RS; AgIn 1.161.687/SP; REsp 1.330.028/DF; REsp 1.268.233/DF; REsp 1.269.841/SP; REsp 1.021.688/RJ; REsp 1.334.097/RJ; AgRg no AgIn 705.630/SC; AgRg no AgIn 1.345.989/SP; REsp 1.005.278/SE; REsp 1.191.875/SE; REsp 1.237.401/PE; AR 4.490/ DF; REsp 1.095.385/SP; REsp 1.420.285/MA; REsp 1.263.973/DF; REsp 1.171.331/DF; REsp 1.308.885/ RJ; REsp 1.335.153/RJ; REsp 1.235.637/DF; REsp 1.331.098/GO; REsp 645.729/RJ; REsp 680.794/PR; REsp 1.297.567/RJ; REsp 334.827/SP; REsp 980.132/PI; REsp 1.125.355/SP; REsp 984.803/ES; AgRg no AgIn 1.205.445/RJ; AgRg no REsp 977.219/SP; AgRg no AREsp 145.387/SC; RMS 27.549/SP; HC 198.402/BA; REsp 863.993/PB; REsp 801.109/DF; AI 777.203 ED/PR; REsp 794.586/RJ; REsp 685.933/ DF. Desses, apenas 18 jurisprudências tiveram argumentos explicitados ao longo da pesquisa, tendo em vista a limitação de espaço e por apresentarem conclusões relevantes e representativas quanto aos demais julgados omitidos.

53 BRASIL. STF, AI 777.203 ED/PR, Rel. Ministra Cármen Lúcia, 1. T., julgado em 14.06.2011, DJe de 30.06.2011. Emb. decl. no agravo de instrumento 777.2013 Paraná. Disponível em: <http://redir. stf.jus.br/paginadorpub/paginador.jsp?docTP=AC\&docID=624917 >. Acesso em: 14 jul. 2015.

54 BRASIL. STJ, RMS 27.549/SP, Rel. Ministra Laurita Vaz, 5. T., julgado em 27.03.2012, DJe de 03.04.2012. Disponível em: <https://ww2.stj.jus.br/processo/revista/documento/mediado/?componente $=$ ITA\&Seq uencial $=1134954 \&$ num_registro $=200801763718 \&$ data $=20120403 \&$ formato $=P D F>$. Acesso em: 14 jul. 2015.

55 RONCAGLIA, Daniel. Judiciário, imprensa e políticos tiram a paz de Vinhedo. Consultor Jurídico. Disponível em: <http://www.conjur.com.br/2007-jul-28/judiciario_imprensa_politicos_tiram_paz_vinhedo >. Acesso em: 7 jul. 2015. 
56 BRASIL. STJ, REsp 1.120.971/RJ, Rel. Ministro Sidnei Beneti, 3. T., julgado em 28.02.2012, DJe de 20.06.2012. Disponível em: <https://ww2.stj.jus.br/processo/revista/documento/mediado/?componen te $=$ ITA\&sequencial $=1124378 \&$ num_registro $=200801126537 \&$ data $=20120620 \&$ formato $=P D F>$. Acesso em: 12 jul. 2015.

57 BRASIL. STJ, REsp 1.374.177/GO, Rel. Ministro Luis Felipe Salomão, 4. T., julgado em 05.09.2013, DJe de 28.10.2013, p. 01. Disponível em: <https://ww2.stj.jus.br/processo/revista/documento/mediado $/$ Componente $=I T A \&$ sequencial $=1261339 \&$ num_registro $=201101108512 \&$ data $=20131028 \&$ form ato $=$ PDF $>$. Acesso em: 12 jul. 2015.

58 BRASIL. STJ, AgRg no REsp 1.354.696/PR, Rel. Ministro Paulo de Tarso Sanseverino, 3. T., julgado em 23.10.2014, DJe de 31.10.2014. Disponível em: < https://ww2.stj.jus.br/processo/revista/documento/ mediado/?componente $=I T A \&$ sequencial $=1360501 \&$ \&num_registro $=201202394085 \&$ data $=20141031$ $\&$ formato=PDF $>$. Acesso em: 12 jul. 2015.

59 BRASIL. STJ, REsp 713.202/RS, Rel. Ministro Luis Felipe Salomão, 4. T., julgado em 1.10.2009, DJe de 3.08.2010, p. 01. Disponível em: <https://ww2.stj.jus.br/processo/revista/documento/mediado/?com ponente $=I T A \&$ sequencial $=916753 \&$ num_registro $=200401845974 \&$ data $=20100803 \&$ formato $=P$ DF >. Acesso em: 12 jul. 2015.

60 BRASIL. STJ, AgIn 1.161.687/SP, Rel. Ministro Vasco Della Giustina, julgado em 30.3.2011, DJe de 6.4.2011. Disponível em: <https://ww2.stj.jus.br/processo/revista/documento/mediado/?componente= $\mathrm{MON} \&$ sequencial $=14744436 \&$ num_registro $=200900387720 \&$ data $=20110406 \&$ formato $=\mathrm{PDF}>$. Acesso em: 12 jul. 2015.

61 BRASIL. STJ, REsp 1.330.028/DF, Rel. Ministro Ricardo Villas Bôas Cueva, 3. T., julgado em 6.11.2012, DJe de 17.12.2012, p. 01. Disponível em: <https://ww2.stj.jus.br/processo/revista/documento/mediado/ ?componente $=I T A \&$ sequencial $=1192425 \&$ \&um_registro $=201200490545 \&$ data $=20121217 \&$ format $\mathrm{o}=\mathrm{PDF}>$. Acesso em: 14 jul. 2015.

62 BRASIL. STJ, REsp 1.268.233/DF, Rel. Ministro Massami Uyeda, 3. T., julgado em 15.3.2012, DJe de 24.4.2012. Disponível em: <https:/ww2.stj.jus.br/processo/revista/documento/mediado/?component $\mathrm{e}=\mathrm{ITA}$ \&sequencial $=1130248 \&$ num_registro $=201101740122 \&$ data $=20120424 \&$ formato $=P D F>$. Acesso em: 14 jul. 2015.

63 BRASIL. STJ, REsp 1.269.841/SP, Rel. Ministra Nancy Andrighi, 3. T., julgado em 17.10.2013, DJe de 25.10.2013, p. 01. Disponível em: <https:/ww2.stj.jus.br/processo/revista/documento/mediado/?comp onente $=I T A \&$ sequencial $=1274550 \&$ num_registro $=201101290896 \&$ data $=20131025 \&$ formato $=P$ DF >. Acesso em: 14 jul. 2015.

64 BRASIL. STJ, REsp 794.586/RJ, Rel. Ministro Raul Araújo, 4. T., julgado em 15.03.2012, DJe de 21.3.2012, p. 1. Disponível em: <https://ww2.stj.jus.br/processo/revista/documento/mediado/?compone nte $=$ ITA\&sequencial $=1131053 \&$ num_registro $=200501834430 \&$ data $=20120321 \&$ formato $=P D F>$. Acesso em: 14 jul. 2015.

65 BRASIL. Superior Tribunal de Justiça. Súmula $n^{\circ}$ 403. Independe de prova do prejuízo a indenização pela publicação não autorizada de imagem de pessoa com fins econômicos ou comerciais.

66 BRASIL. STJ, REsp 794.586/RJ, Rel. Ministro Raul Araújo, 4. T., julgado em 15.3.2012, DJe de 21.3.2012, p. 01. Disponível em: <https://ww2.stj.jus.br/processo/revista/documento/mediado/?componente=ITA $\&$ sequencial $=1131053 \&$ num_registro $=200501834430 \&$ data $=20120321 \&$ formato $=P D F>$. Acesso em: 14 jul. 2015.

67 BRASIL. STJ, REsp 1.021.688/RJ, Rel. Ministro Massami Uyeda, 3. T., julgado em 26.6.2009, DJe de 1.7.2009. Disponível em: <https://ww2.stj.jus.br/processo/revista/documento/mediado/?componente=I TA\&sequencial $=892982 \&$ \&um_registro $=200800032440 \&$ data $=20090701 \&$ formato $=P D F>$. Acesso em: 14 jul. 2015.

68 BRASIL. STJ, REsp 801.109/DF, Rel. Ministro Raul Araújo, 4. T., julgado em 12.6.2012, DJe de 12.3.2013, p. 02. Disponível em: < https://ww2.stj.jus.br/processo/revista/documento/mediado/?comp onente $=I T A \&$ sequencial $=1149023 \&$ num_registro $=200501951627 \&$ data $=20130312 \&$ formato $=P$ DF >. Acesso em: 14 jul. 2015.

69 BRASIL. STJ, REsp 801.109/DF, Rel. Ministro Raul Araújo, 4. T., julgado em 12.06.2012, DJe de 12.3.2013, p. 03. Disponível em: <https://ww2.stj.jus.br/processo/revista/documento/mediado/?comp onente $=$ ITA\&Sequencial $=1149023 \&$ \&um_registro $=200501951627 \&$ data $=20130312 \&$ formato $=P$ DF $>$. Acesso em: 14 jul. 2015.

70 BRASIL. STJ, REsp 1.334.097/RJ, Rel. Ministro Luis Felipe Salomão, 4. T., julgado em 28.5.2013, DJe de 10.9.2013. Disponível em: < https://ww2.stj.jus.br/processo/revista/documento/mediado/?componen 
te $=I T A \&$ sequencial $=1239004 \&$ num_registro $=201201449107 \&$ data $=20130910 \&$ formato $=P D F>$. Acesso em: 14 jul. 2015.

71 BRASIL. STF, AgRg no AgIn 705.630/SC, Rel. Ministro Celso de Mello, 2. T., julgado em 22.3.2011, DJe de 6.4.2011, p. 2. Disponível em: < http://redir.stf.jus.br/paginadorpub/paginador. jsp?docTP=AC\&docID=621516>. Acesso em: 14 jul. 2015.

72 BRASIL. STJ, HC 198.402/BA, Rel. Ministra Laurita Vaz, 5. T., julgado em 22.11.2011, DJe de 1.12.2011, p. 1. Disponível em: <https://ww2.stj.jus.br/processo/revista/documento/mediado/?componente=ITA \&sequencial $=1108129 \&$ num_registro $=201100385497 \&$ data $=20111201 \&$ formato $=P D F>$. Acesso em: 14 jul. 2015.

73 BRASIL. Superior Tribunal de Justiça. Súmula $\mathbf{n}^{\circ}$ 7. A pretensão de simples reexame de prova não enseja recurso especial.

74 BRASIL. Supremo Tribunal Federal. Súmula $\mathbf{n}^{\circ} 279$. Para simples reexame de prova não cabe recurso extraordinário.

FREEDOM OF EXPRESSION AND THE RIGHTTO INFORMATION: THELIMITS OF JOURNALISTIC ACTIVITYUNDERTHEOPTICSOFTHESUPREME FEDERALCOURT ANDTHESUPERIORCOURTOF JUSTICE

\section{ABSTRACT}

Freedom of expression and the right to information are fundamental rights that guide journalistic activity. Due to their relative character, however, they may come into collision with other rights, such as honor, image and privacy. This study aims, therefore, at explaining the legal and ethical limits and the legal liabilities attributable to journalists and media outlets due to professional practice; to study the rule of proportionality as a method of resolving conflicts between fundamental rights; to analyze the higher courts' jurisprudential understanding about the conflict between freedom of expression and the right to information versus other fundamental rights and how these principles have been relativized. Thus, 41 decisions rendered by the Supreme Federal Court and the Superior Court of Justice in the period between April 30, 2009 and April 30, 2015 are analyzed in order to clarify which of the conflicting rights have prevailed or not in a particular case, trying to get the most reliable answer about the real limits of journalistic performance and understand if what has been tried has established precedents. The research is based on qualitative and quantitative analysis and is descriptive and inductive. The study is justified by 
the originality of the thematic approach and the lack of academic studies dealing with the clash between freedom of expression and the right to information versus other fundamental rights through empiricism. The results seek to aid the reflection on media exercise, assessing how journalistic activity can serve society without committing unlawful acts or abusing its underpinning rights.

Keywords: Freedom of expression. Right to information. Collision of fundamental rights. Jurisprudence. Superior Courts. 